\title{
Sutan Sjahrir's Footprint in Egypt, Middle East: A History That Is Almost Forgotten
}

\author{
Herdi Sahrasad $^{1}$, TI Aisyah ${ }^{2}$, Dedy Tabrani ${ }^{3}$, Mohamad Asrori Mulky ${ }^{4}$ \\ ${ }^{1}$ Associate Director Paramadina Institute for Ethics and Civilizations, University of Paramadina and Centre \\ for Strategic Studies University of Indonesia (CSS-UI) \\ ${ }^{2}$ Lecturer at University of Malikussaleh Aceh, Indonesia \\ ${ }^{3}$ PhD Candidate at Police Science College, PTIK, Jakarta, Indonesia \\ ${ }^{4}$ Lecturer at Tarbiyah College of Sciences Darul Fatah, Jakarta, and Researcher at the University of \\ Paramadina Institute of Ethics and Civilizations \\ sahrasad@yahoo.com
}

\section{Abstract}

This article argues that the Indonesian people will never forget the services and roles of Egypt, the country that first recognized Indonesian independence. History recorded that the first recognition of the sovereignty of Indonesia is not done by Western countries, especially the United States who often claim him as a promoter of freedom and human rights (human rights). Indonesia's struggle for independence is supported firstly and heroically by the Muslim countries in the Arab, not others because of the spiritual-emotional relationships and civil Islam in all of the countries and nations. At that time, Arab world have felt, how strong ukhuwah Islamiyyah (Islamic solidarity and linkage) between the Indonesian people and with Arab nations who are struggling for their independence.
Keywords

Egypt; Dutch colonial; Islamic Wbrld Indonesian independence; Hassan Al-Banna: Ikwanu Mustimin

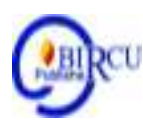

\section{Introduction}

In M. Zein Hasan's notes in his book ''Diplomasi Revolusi Indonesia di Luar Negeri", (Diplomacy of the Indonesian Revolution Abroad, Bulan Bintang, 1980), Hasan al-Banna and the Muslim Brotherhood were among those who were very enthusiastic and gave strong support for Indonesia's independence. The Muslim Brotherhood from the beginning was involved in the formation of the 'Indonesian Defenders Committee' at the Syubbanul Muslimin building, Cairo, on October 16, 1945. The committee, led by General Saleh Harb Pasya and involved many Egyptian figures and several other Arab countries, then drafted a resolution and efforts to support the independence of Indonesia.

Hasan al-Banna himself was then actively involved in this 'Indonesian Defending Committee' and met with Indonesian independence figures who visited Egypt to garner support for Indonesia. Al Banna mobilized Islamic masses in Egypt to urge the Egyptian government to recognize Indonesian independence.

In the context of the Muslim Brotherhood in Egypt at that time, peaceful or nonviolent Islamist mobilization had included the following actions: forming mass organizations, political parties, competing in elections, developing civil society-state partnerships, and establishing social community organizations. It might also include working with government agencies to support Sharia-based policies. This Islamist mobilization in Egypt included mobilizing the masses to support Indonesia's independence, driving out the enemies of the people and the state, resisting colonialism and imperialism 
Konfrontasi Journal: Culture, Economy and Social Changes, 7 (2) June 2020, 105-115

ISSN: 1410-881X (Print), 2716-2095 (Online)

Herdi Sahrasad, TI Aisyah, Dedy Tabrani, Mohamad Asrori Mulky: Sutan Sjahrir's Footprint in Egypt, Middle East: A History That Is Almost Forgotten

DOI: https://doi.org/10.33258/konfrontasi2.v7i2.104

http://www.konfrontasi.net/index.php/konfrontasi2

attacking certain persons or groups who oppressed the common people, mobilizing PanIslamism, carrying out revolutionary movements and so on.

As history records, in April 1947, an Indonesian government delegation led by H. Agus Salim arrived in Egypt to formalize relations between the two countries. The group met with King Faruk, Secretary General of the Arab League, and several other figures. H. Agus Salim expressed his gratitude for Indonesia's support of Egypt, the Arab League, and many other parties, as well as strengthening the existing friendly relations between them. On that occasion, H. Agus Salim also took time to meet with Hasan al-Banna. The same thing was done by Sutan Syahrir when he came to Cairo some time later. When the Dutch carried out the first Military Aggression in July 1947, Egyptian society demonstrated against the Dutch action. Included in the demonstration were 'militant workers, mainly from the Muslim Brotherhood, carrying red and white flags, and pictures of King Faruk'

On June 6, 1947 in Yogyakarta, still was in an atmosphere of revolution, President Sukarno accepted a group of Indonesian youths who had just come from Egypt. They stayed for about two hours in a state palace. To the young men, President Sukarno reminded that the recently established Republic of Indonesia was a joint capital and fortress for the Indonesian people. "Capital to be enlarged and fortifications to be maintained," he said.

On the same occasion, the young men delivered some gifts they had brought from Egypt to President Sukarno and his wife in the form of authentic Egyptian cigars and ivory perfume containers. In addition, these young men also brought several letters to the President of Indonesia from several well-known people in Egypt, namely General Sholeh Harb Pasya (Subah Muslimin), Hassan Bannah (Ichwanul Muslimin), and Nahas Pasha (Party Wafd). This meeting was reported three days later by the Repoeblik Daily in a short article entitled 'Letters from Egypt to the President'.

The figure written as Hassan Bannah above is actually named Hasan al-Banna (19061949), the founder and leader of al Ikhwan al Muslimun, known as the Ikhwanul Muslimin (IM). It is very likely that the letter contained support for the Republic of Indonesia to continue to maintain its independence.

Hasan al-Banna has mobilized the people of Egypt to support Indonesia's independence . And we need to realize that before March 22, 1946, Indonesia had been always claimed by the Netherlands as their colonial country, that the internal affairs in this country was a domestic problem in the colonial country. The Netherlands still claims Indonesia as a colony. At the same time, the conditions of the state of Indonesia were incomplete even though de facto Indonesia had been established since 17 August 1945.

\section{Review of Literature}

\section{Egypt and Indonesian Independence}

Prior to March 22, 1946, foreign countries and the United Nations (UN) did not want to interfere with Indonesian affairs because they were seen as problems within the Netherlands. At that time, the international community did not want to take care of Indonesia's problems despite the war in Indonesia and many casualties.

Prior to March 22, 1946, Indonesian delegations such as Sutan Sjahrir, Haji Agus Salim, Soedjatmoko, LN Palar, were not allowed to enter the UN General Assembly. What Happened on March 22, 1946? That was the date when a country recognized Indonesian independence for the first time. That country is Egypt. Even a year before independence was proclaimed, Palestine, through its Grand Mufti, Shaykh Muhammad Amin Al-Husaini had expressed his support for Indonesia. On September 6, 1944, Arabic Radio Berlin broadcast 
'congratulations' from Shaykh Amin Al-Husaini to the entire Islamic world to support Indonesian independence.

Since Egypt and Palestine have recognized and supported Indonesia's independence, the countries in the Middle East have flocked to recognize Indonesian independence. Not only that, India then followed Egypt and Palestine. In addition to Agus Salim's expertise in lobbying Middle Eastern countries, it was also due to the support of Islamic movements in the Middle East in general and Egypt in particular.

Starting from Mansur Abu Makarim, an Indonesian informant who worked at the Dutch Embassy in Cairo, Egypt who read in the Vrij Netherland Magazine which reported that the Indonesian State had proclaimed its independence, then informed the newspapers and radio in Egypt. Egyptians and members of Islamic organizations are happy. Egyptian newspapers and radio say that this is the beginning of a revival in the Islamic world. It was also stated that this was the beginning of the independence of the countries in the Islamic world to be free from the shackles of colonialism in Western countries. On October 16, 1945 a number of scholars in Egypt and the Arab World with their own initiative formed the 'Difa'i Lajnatud Indonesia' (Indonesian Defense Committee). The Muslim Brotherhood, based in Egypt and led by Hasan Al Banna, was at that time the main element of this movement.

Since then the Muslim Brotherhood has often held large-scale demonstrations urging the Egyptian government to recognize Indonesian independence. Egyptians and members of Islamic organizations are happy. Egyptian newspapers and radio say that this is the beginning of a revival in the Islamic world. It was also stated that this was the beginning of the independence of the countries in the Islamic world to be free from the shackles of colonialism in Western countries.

On October 16, 1945 a number of scholars in Egypt and the Arab World with their own initiative formed the 'Difa'i Lajnatud Indonesia' (Indonesian Defense Committee). The Muslim Brotherhood, based in Egypt and led by Hasan Al Banna, was at that time the main element of this movement.

Since then the Muslim Brotherhood has often held large-scale demonstrations urging the Egyptian government to recognize Indonesian independence. The sailors who worked on British ships did strike many and even stopped working and filed demands on the British government to stop helping the Dutch.

There was even an Indonesian student, Mohammad Zein Hassan, who worked on a British ship in Tunisia, stopped working on that British ship and walked from Tunisia to Egypt.When asked why he walked that far, Zein Hassan replied, "All transport companies from Tunisia to Egypt are British-owned and scholars in Egypt forbid cooperation with Britain to help the Dutch obstruct Indonesian independence!"

At that time the Muslim Brotherhood also opened the widest possible space for Indonesian students in Egypt to write about Indonesian independence in Ikhwan's newspapers and magazines. When the Surabaya battle took place on November 10, 1945 and many Indonesian newspapers reported, the Muslim Brotherhood and other Islamic movements held unseen prayer in congregation in many places in Egypt.

At the urging of the Muslim Brotherhood and other Islamic movements finally the Egyptian State under the leadership of King Farouk at that time recognized Indonesian independence on March 22, 1946. After that the Egyptian government sent its special envoy to carry the letter of acknowledgment to meet President Soekarno in the Indonesian capital, Yogyakarta. This was a hard struggle because at that time Indonesia was blocked by the Dutch. It takes courage and special skills like John Lie to penetrate the Dutch blockade.

Tothe movement activists and actors in Arab and reporters who came crowding Sjahrir in Cairo, Sjahrir stated: "My departure to New York based on official appointment of 
President of the Republic of Indonesia, Soekarno (for Indonesian struggle against Ducth colonialists through diplomacy) ."

About the question of Arab journalists: "Whether Indonesia is a sovereign state? Answered by Sjahrir: "The UN Security Council has approved to put Indonesia in the show, it was a clear recognition that Indonesia has full sovereignty."

About the Indonesian issue itself, Sjahrir stated: "The issues of Indonesia all have to be brought to international court, as we carry out the cease-fire order issued by the UN Security Council, and following the advice of India and Australia regarding the dispute was submitted to the UN General Assembly. Because the cease-fire will only give benefit for the Dutch, if they are left entrenched in the areas they occupied. "

When he asked by reporters whether the Egyptian and Arab Indonesia will join the Arab League, Sjahrir answered with a smile: "It is impossible, because Indonesia is not the Arab countries. However, as an Muslim majority state, it is important for Indonesia to cooperate closely with the Arab and Islamic World . "

Sjahrir thanked the leaders of Arab and Islamic world who have been supporting Indonesia, especially Egypt, which has spearheaded to support it. Soon Haji Agus Salim interjected by saying that he has asked Dr Syahrir stopover in Cairo a day or two days to meet with the leaders of Egypt and Arabia, and if it is given the opportunity, they expected to audience with King Farouk, Egypt's head of state.

Sutan Syahrir, more often called Syahrir, is an accomplished diplomat and humanist First Prime Minister of the Republic of Indonesia. Despite the ups and downs due to various opposition within the nation itself, the Syahrir I Cabinet, Sjahrir II Cabinet to Sjahrir III Cabinet (1945 to 1947) consistently fought for the sovereignty of the Republic of Indonesia through diplomacy. Syahrir did not want to be silly to face an allied army which was clearly far more sophisticated in terms of weapons. His diplomacy then led to a temporary victory. Britain as the command of the allied forces for the Southeast Asian region urged the Dutch to sit in negotiations with the republican government. Politically, this means that the de facto ally recognizes the existence of the Indonesian government.

The winding road of diplomacy was clouded by the onslaught of the Dutch military action on July 21, 1947. The Dutch action actually brought Indonesia to the United Nations (UN) forum. After no longer serving as Prime Minister (Cabinet Sjahrir III), Syahrir was sent to represent Indonesia at the United Nations. With the help of Biju Patnaik, Syahrir and Agus Salim went to Lake Success, New York via New Delhi and Cairo to rally support for India and Egypt.

Syahrir can run diplomacy politics to fight for international recognition of Indonesia. Although Sjahrir managed to attract sympathy abroad, but at home he lacked the support of the people. This can be shown by the emergence of various domestic challenges he faced while serving as prime minister.

Sjahrir was able to determine Indonesia's position in the eyes of the international world and convince the Allies that the Republic of Indonesia was not made in Japan. Basically, Sjahrir's existence was not a substitute, but rather as the most appropriate and vital complement to Soekarno-Hatta. The leadership of the Indonesian independence revolution is in the hands of three leaders who support each other and is often called the de facto triumvirate, Soekarno-Hatta-Sjahrir

On August 14, 1947 Syahrir addressed the UN Security Council session. Faced with representatives of the nations of the world, Syahrir described Indonesia as a nation which had centuries of civilization and was exploited by the colonials. Then, expertly Syahrir broke one by one the arguments that had been presented by the Dutch representative, Eelco van Kleffens. With that, Indonesia succeeded in seizing its position as a nation that fought for its 
sovereignty in the international arena. The UN also intervened, so that the Netherlands failed to maintain its efforts to make the Indonesia-Dutch dispute as a matter that was solely a matter of domestic affairs.

Syahrir was popular with journalists covering the UN Security Council session, especially journalists who were in Indonesia during the revolution. Some newspapers named Syahrir as The Smiling Diplomat.

During the day and night August 5, 1947 in Cairo, Sjahrir has met Ibrahim Abdul Hadi Pasha, Chief of Cabinet of the King. Apart from Indonesia expressed gratitude to the King Faruk, also explains the development of political and military situation in Indonesia. Then Sjahrir visit the Ministry of Foreign Affairs and met its Secretary General Kamil Bey and Ibrahim Abdulrahim Ibazah Basuki, his Secretary of State ad interim. The meeting, which lasted one and a half hour has given opportunity for Bung Sjahrir to explain the IndonesiaNetherlands conflicts with wide-ranging .

About the question of Arab journalists: " whether Indonesia is a sovereign state?Answered by Sjahrir: "The UN Security Council has approved to put Indonesia in the show, it was a clear recognition that Indonesia has full sovereignty."

About the Indonesian issue itself, Sjahrir stated: "The issues of Indonesia all have to be brought to international court, as we carry out the cease-fire order issued by the UN Security Council, and following the advice of India and Australia regarding the dispute was submitted to the UN General Assembly. Because the cease-fire will only give benefit for the Dutch, if they are left entrenched in the areas they occupied. "

When asked by reporters whether the Egyptian and Arab Indonesia will joint the Arab League, Sjahrir answered with a smile: "It is impossible, because Indonesia is not the Arab countries. However, as an Muslim majority state, it is important for Indonesia to cooperate closely with the Arab and Islamic World."

Sjahrir thanked to the leaders of Arab and Islamic world who have been supporting Indonesia, especially Egypt, which has spearheaded support it. Soon Haji Agus Salim interjected by saying that he has asked Bung Sjahrir stopover in Cairo a day or two days to meet with the leaders of Egypt and Arabia, and if it is given the opportunity, they expected to audience with King Farouk, Egypt's head of state.

Because the day coincided with the 18 Ramadan 1366, Bung Sjahrir with members of Permanent Mission of Indonesia break the fast at the Muhammad Ali Club at the invitation of Egyptian Foreign Minister ad interim, and his Chief Representative of Arab League in Cairo, the Egyptian movement leaders such as Hassan al-Banna (Chairman of the Muslim Brotherhood), religious leaders and officials of Egypt and the other Arab figures.

Sjahrir also held a special meeting with Hassan Al-Bana and the Muslim leaders and other Brotherhood activists at the headquarters of the Islamic organizations in Egypt. Hassan Al-Bana said it is ready to mobilize the supports for the movement in Egypt and the MiddleEast for the struggle of Indonesian people under Sukarno-Hatta-Sjahrir, in order to maintain independence. Sjahrir replied, Indonesia requested the supports of Egypt and Arab countries to fight against colonialsm and he then expressed his deep gratitude.

At that time, Hassan Al-Bana lead the Muslim Brotherhood, an Islamic organization that is very strongly urge the government of Egypt and the Arab League in order to fully support Indonesia. Ikhwanul Muslimlin under the leadership of Hassan Al-Bana is also very strongly against the Dutch attacking Indonesia again, which in his perception is a symbol of the return of European colonialism(Western) in the Muslim world. Through Sjahrir and his solid team, the Republic of Indonesia officially denounce the Dutch military aggression to the UN Security Council, because aggression is judged to have violated an international treaty, the Linggarjati Treaty. 
The iftar banquet was best chance for Sjahrir to explain about Indonesian problems to all of representative Arab leaders and political parties officials, and Sjahrir expressed his great and sincere appreciation to the Arab world who have the attention, commitment and friendship for Indonesian independence.

\section{Discussion}

\subsection{Sjahrir's Diplomacy and Muslim Brotherhood (Ikhwanul Muslimin)}

Spirit'ukhuwah Islamiyah' (Islamic solidarity and linkage) used by Sjahrir (with Haji Agus Salim) in doing diplomacy for Indonesian independence in Egypt, has been become a" magnet" that spark "magnitude of sympathy and supports" from the Islamic countries in general and Middle East countries in particular.

Ikwanul Muslimin newspaper published by the Muslim Brotherhood under Hassan Al Bana leadership in Egypt, throughout the month of October 1947, states that the expression of ukhuwah Islamiyah from Dr. Sjahrir, a statesman and leader of the Socialist Party of Indonesia, is very interesting, with his recognition that Indonesia independence have gain a full confession and recognition from the Islamic countries before Indonesian independence achieved two years old.

Sjahrir's statement to the newspaper "Ikhwanul Muslimin" (5/10/1947 edition, as Hassan Zein translation) is very affirming:" I believe that the Arab world's support for Indonesia con note more than merely friendship. This movement envisioned a force that will lead to unity comprehensively all of the Muslim world."

For Sjahrir who really understand the aspirations and soul of the Muslim World, he saw the reality of a growing trend among Islamic solidarity in the world, including its direction toward unity and consolidation in the sense that it move progressively to solidarity of Islam that aims to breakdown the chains of hegemonic foreign rule and imperialism.

"In this regard, Indonesia is also supporting fully the struggle of Pakistan, Indonesia as a Muslim country will struggle in the Muslims front," said Sjahrir at that time when hegaveits views for journalist from Ikhwanul Muslimin newspaper on the struggle of Pakistan people for independence to answer concerning the upheaval in Pakistan.

When answering reporter's questions "An-Nida' daily dated18/11/1947, Sjahrir also stated that:" No doubt that the Muslims and Arab shave a major role in world politics, the political unity and the common understanding of the tactics and strategy. The important thing is that they are good in using their power, especially In the Middle East, an important area that has been battle ground for spread of influence and contention between the two blocks(Block Soviet/Communist Bloc and the U.S./Capitalist Bloc)."

Explaining the two Bloc (communist versus capitalist), indeed Sjahrir has revealed the coming of Cold World era with its political implications for Indonesia.

Sjahrir believe that, if the Arab World could use cleverly of such forces, then they can be an effective factor in the dinamiycs of the situation and in creating a balance of international powers, especially in the Middle East and Islamic World.

Sjahrir in Cairo gained substantial support from the fighters, activists and Arab leaders who want a fully sovereign and independent Indonesia. From Cairo, then Sjahrir flied to the U.S. The strong support from Egypt, including the Muslim Brotherhood, increasingly strengthened Sjahrir's spirit in the UN Security Council meeting in Lake Success, New York, which he passes through the steep and winding road.

The meeting of the United Nations Security Council on August 14, 1947 in Lake Success, New York, United States, finally took place. Sutan Sjahrir, a Malay-faced young man, curly haired, age 38, his height is less 1.60 meter, break down calmly his views. From 
the way he spoke, he seemed not to be trapped the provocative statements of Eelco R. Kleffens van, one of which represents the opposite camp (the Netherlands). Kleffens, a senior official of the Dutch foreign ministry. Rather than developing arguments, Kleffens expose bad behavior among various "republican". "Which do you believe: they are or civilized people like us," so he closed his presentation, as recorded in the video documentation of Des Alwi.

Sutan Sjahrir, replied calmly, his arguments did not move from one point: the Dutch have breached the Agreement of Linggarjati. "I believe that board members can judge, whether the allegations of Netherlands are true or false. But there is one fact which I wish to emphasize: the Dutch do not deny all the facts are revealed on my last statement, in which the Dutch betrayed and violated the Linggarjati Treaty. Rather than refute my statement, The Dutch actually filed charges not proven, "he said fluently in English. He tells the story of the triumph of Indonesia thousand years ago in the formation of the kingdom of Majapahit, then, displays the image contrast. "However, since the Dutch colonial during three and a half centuries in the past, our nation suffered a total setback," he said. Sjahrir dismissed the notion that Japan has the granting of independence for Indonesia, he asked for UN assistance to act as a mediator in the Indonesia-Netherlands conflict, and requested that the UN should issue a decision to force the Dutch troops withdraw from the republic. Unfortunately, the demand was not met.

Even so, according to Charles Wolf, author of The Indonesian Story: The Birth, Growth, and Structure of the Indonesian, the victory remained in the young republic. "Sjahrir's speech was attractive, sophisticated and efficient," Wolf writes. That is why, influential newspaper in the land of Uncle Sam, New York Herald Tribune, on August 15, 1947 revealed Sjahrir speech as "one of the most thrilling in the UN Security Council". From there, the support of the international communities flowed for Indonesia.

Not only from the friends like India, Philippines, Australia, and Syria, but also from countries such as Russia and Poland. Commission's three-member countries Australia, Belgium, and the United States was formed as mediator for the Indonesia-Netherlands conflict. Most importantly, the Netherlands failed to implement this wish: a unilateral approach by the armed forces. On July 30, 1947, India and Australia filed a formal letter of request addressed to the case of Indonesia in the UN Security Council meeting. Despite opposition from the Dutch colonialists and the trio of Britain, France, and Belgium, both countries accepted the request by voting members of the council on August 12, 1947.

According to the historian Rushdy Hoesein, Sjahrir's speech at the Security Council is made possible because of the article in the Treaty of Linggarjati arbritase. This is the crucial moment that makes Indonesia appeared on the international scene. Indonesia's name echoed from the UN headquarters in Lake Success, New York in 1947 through Sjahrir's diplomacy, in which the Arab/Islamic world supported it.

The Netherlands did not take into account the strong reaction from the international community, including the UK, which is no longer approve a military settlement. At the request of India and Australia, on July 31, 1947, this issue of military aggression launched by the Dutch incorporated into the agenda of the UN Security Council, which then issued Resolution No. 27 dated August 1, 1947, which it called for an armed conflict to be stopped.

The UN Security Council acknowledged the existence of de facto Republic of Indonesia. This recognition is evidenced in all the UN resolutions since 1947, and the UN Security Council officially use the name of Indonesia, and not the Netherlands Indies anymore. Since the first resolution, that is resolution No. 27 on 1 August 1947, then the resolution No. 30 and 31 dated 25 August 1947, resolution No. 36 on 1 November 1947, (and 
later resolution No. 67 dated January 28, 1949), the UN Security Council has always said the conflict between the Republic of Indonesia and the Netherlands as The Indonesian Question.

Pressure on the UN Security Council, on August 15, 1947, eventually the Dutch government said it will accept the resolutions of the Security Council to stop the fighting. On August 17, 1947 the Government of the Republic of Indonesia and the Dutch government accepted the Security Council resolution for a ceasefire, and on August 25, 1947 the Security Council would establish a committee to mediate the conflict between Indonesia and the Netherlands. The committee initially only as a Committee of Good Offices for Indonesia (Committee of Good Offices for Indonesia), and better known as the Committee of Three Kingdoms (KTN), because it consists of three countries, namely Australia selected by Indonesia, Belgium and the Netherlands are selected by the United States as a neutral party. Australia was represented by Richard C. Kirby, Belgium was represented by Paul van Zeeland and the United States appointed Dr. Frank Graham.

Here it is clear that Sjahrir's diplomacy has significant role in the formative years of Indonesian independence, in which his journey to Cairo before departing to New York, has had historical milstone in building relationship with Ikhwanul Muslimin (Muslim Brotherhood) and Arabic leaders to support strongly Indonesian independence.

\subsection{Sjahrir Come Back to Cairo}

When SutanSjahrir stopped again in Cairo on his way to go home from the UN Security Council, New York, he has held talks with Prime Minister Mahmud Fahmi Pasha Nokrasyi cum Foreign Minister of Egypt, discussed the relationship between Indonesia and Egypt. In the talks, they have agreed upon improving diplomatic relations between the two countries at the embassy level. At that time, the embassy is only owned by large countries. The approval of the Egyptian Foreign Ministry for the ste-up of Indonesian embassy in Cairo had been broad cast on November 19, 1947, as the implementation of previously signed agreement son June 10, 1947

At that time, Sjahrir met and thanked Hassan Al-Bana and Muslim Brotherhood for their real supports to Indonesian struggle for independence through diplomacy and politics that involved the Arab World.

On 20November 1947, the daily Al-Ikhwanul Muslimin published by the Muslim Brotherhood organization under the leadership of Hasan al-Banna re-broadcast the news as follows::" His Majesty the King Faruk was pleased yesterday, he signed to handle the opening of the Royal Decree on the Egyptian Embassies in Pakistan, India, Indonesia and Australia, and the opening of consulates in Cyprus and there has been agreement between Dr. Sjahrir, former Prime Minister of Indonesia, when he was in Cairo and before leaving the city to Pakistan."

The Ikhwanul Muslimin newspaper published the Sjahrir's diplomacy and talk to Arab Leaders in Cairo to empower and amplify Indonesian interest to get the Arab World's support for Indonesian independence with full commitment.

Fascinated by the personality of Sjahrir, the Special Representative of the Arab League who committed to Indonesia, Muhammad Abdulmun'im, also saying as follows: "Dr. Sjahrir is a prominent leader of Indonesia, although he was a young, that was only thirty-seven years. $\mathrm{He}$ is a competent and good statesman, so that Lord Killearn, the British High Commissioner in South East Asia, admitted that he had not been met a diplomat who has so strong and clever argument during his day in the field of diplomacy such as Dr. Sjahrir, who give cleverly a deep understanding." 
Historical traces of Sjahrir, Haji Agus Salim, and other Indonesian fighters for diplomacy in the Middle East imprinting the deep meaning for Egypt and the Arab world, particularly in line with support of Indonesia under Soekarno-Hatta for Palestinian independence that Sjahrir has articulated firmly.

About Palestinian issue, Sutan Sjahrir articulated as follows: "Indonesia opposed the partition of Palestine between original Arabs and the Jewish settlers by force, as suggested by the UN international commission." And Indonesia condemned the establishment of the commission that Sjahrir said it was not guided by the reality of life in Palestine and ignored the justice and righteousness. The Palestinian issue is essentially a matter of truth, justice and independence. Therefore, it became both the Arab and Muslim issues entirely. Indonesia's fight against colonialists and ruthlessness is also oppose vehemently the partition of Palestine , and Indonesia stood beside his brothers namely Arab countries and Islamic ummah as well as the lovers of truth and justice, until Palestine can achieve full independence and gain their rights in full too.

Egypt and the Arab League strengthened their support for the independence of Indonesia with Sjahrir's visits that is able to convince the Arab world about how important their supports for our struggle for full independence. History recorded that the first recognition of the sovereignty of Indonesia is not done by Western countries, especially the United States who often claim him as a promoter of freedom and human rights (human rights). Indonesia's struggle for independence is supported firstly and heroically by the Muslim countries in the Arab, not others because of the emotional relationships and civil Islam in all of the countries and nations. At that time, Arab world have felt, how strong ukhuwah Islamiyyah (Islamic solidarity and linkage) between the Indonesian people and with Arab nations who are struggling for their independence.

In the Middle East, Egypt recorded as the first country to recognize Indonesia's independence proclamation. This is not apart from the emotional closeness of national figures such as Sutan Sjahrir, M.Natsir, H. Agus Salim, etc. with figures of the Islamic movement in Egypt, such as Hassan al-Bana of the Muslim Brotherhood who are also fighting for the independence of the other Islamic countries. Then in its development, from Egypt, the support of other Arab countries for Indonesian independence spread ot in Middle East. .

The Arab countries giving recognition to the Republic of Indonesia after Egypt (the first) is Syria, Iraq, Lebanon, Yemen, Saudi Arabia and Afghanistan in South Asia. In addition, the Arab League also played an important role in the recognition of Indonesian independence. Officially, the Arab League Council's decision dated on November 18, 1946 have advised to all member states of the Arab League to recognize Indonesia as a sovereign and independent state. The reason of the Arab League to give support to Indonesian independence was based on religious ties, brotherhood and common destiny.

Support of the Arab League to be answered by President Soekarno who declared that the Arab countries and Indonesia have long lasting relationship "because among us there is a reciprocally religious linkage (Islam) ".

While Sutan Sjahrir's statement to support Arab states expressed in the Daily Ikhwanul Muslimin of Muslim Brotherhood, Egypt: "It is a fact, there is a tendency to expand the Islamic Ummah in the world toward the unity and consolidation of the Islamic solidarity that aimed at the breakdown of the chains of foreign occupation and colonialism. In this regard, Indonesia supports Pakistan fully. And Indonesian as a Muslim country will fight in the ranks of the Muslims."

Recognition of Egypt and the Arab countries for Indonesia has been through a long and heroic process. Once the information of proclamation of Indonesia independence spread around the world, the Egyptian government sent directly Consul-General in Bombay named 
Mohammad Abdul Mun'im to Yogyakarta (then the capital of Indonesia) by breaking through the Dutch blockade to deliver official documents of recognition of Egypt to the Republic of Indonesia. This is the first time in the history in which a country's mission through a person to convey recognition of his country to the other country besieged by colonialists, even also by risking his life. This is also the first foreign official envoy who visited the capital of the Republic of Indonesia

Recognition of Egypt were then reinforced with the signing of the Treaty of Amity Indonesia-Egypt in Cairo. Before signing the agreement, the Dutch ambassador in Egypt was very tension and panic, he stormed into his office of Prime Minister Nokrasi Pasha of Egypt to protest it. Before the signing of the agreement, the Dutch ambassador put pressure to the PM Pasha not to sign it the arrival of the Dutch ambassador aims to remind Egyptians of Egypt's economic relations with Netherlands as well as the promise of Dutch support for Egypt on the Palestinian issue at the UN.

Responding to the protests and the threat of Dutch, PM Pasha of Egypt gave the following answer: "Sorry sir, we must reject the protest, because Egypt as a sovereign state and a state based on Islam cannot but support the struggle of Muslim Indonesia. This is the tradition of the Egyptians and cannot be ignored".

King Farouk of Egypt also expressed reason for Egypt and the Arab League to support Indonesia, saying "because the Islam fraternity and solidarity, in particular, we assist and encourage the Arab League to support the struggle of the Indonesian nation and acknowledge the sovereignty of the country."

\section{Conclusion}

As a trusted person of President Soekarno, Sjahrir has historical relations with Egyptian leaders, specifically Hasan Al Banna, Founder of the Muslim Brotherhood. Sjahrir also held a special meeting with Hassan Al-Bana and the Muslim leaders and other Brotherhood activists at the headquarters of the Islamic organizations in Egypt.

At that time, Hassan Al-Bana said it was ready to mobilize the supports for the movement in Egypt and the Middle East for the struggle of Indonesian people under SukarnoHatta-Sjahrir, in order to maintain independence. Sjahrir replied, Indonesia requested the supports of Egypt and Arab countries to fight against colonialism and he then expressed his deep gratitude. The Arab countries giving recognition to the Republic of Indonesia after Egypt (the first) is Syria, Iraq, Lebanon, Yemen, Saudi Arabia and Afghanistan in South Asia. In addition, the Arab League also played an important role in the recognition of Indonesian independence.

We must admit that the historical point of Sjahrir, Haji Agus Salim, and other Indonesian fighters for diplomacy in the Middle East imprinting the deep meaning for Egypt and the Arab world, particularly in line with support of Indonesia under Soekarno-Hatta for Palestinian independence that Sjahrir has articulated firmly.

\section{References}

John D. Legge, Kaum Intelektual dan Perjuangan Kemerdekaan: Peranan Kelompok Sjahrir , Grafiti: Cetakan Pertama 1993

Rudolf Mrazek, Sjahrir: Politics and Exile in Indonesia, Ithaca: Cornell University Southeast Asia Program,1994.

A.B Lapian \& P.J Droglever, Menelusuri Jalur Linggarjati, Jakarta: PT Temprint,1992. 
Ide Anak Agung Gde Agung, Persetujuan Renville- Prolog dan Epilog, (Solo, Yayasan Pustaka Nusatama,1995).

M.C. Ricklefs, Sejarah Indonesia Modern 1200-2004, Jakarta: Serambi Ilmu Semesta, 2005, hlm 428-468.

Zein Hassan, Diplomasi Revolusi Indonesia di Luar Negeri, Jakarta: Penerbit Bulan Bintang, 1980.

Erni Haryanti Kahfi, Islam and Nationalism: Agus Salim and Nationalist Movement in Indonesia During the Twentieth Century, Jakarta:Logos, 2001..

Abdurrahman, Peranan Agus SalimMenjelang dan Sesudah Kemerdekaan Indonesia (19421954), paper, Program Pasacasarjana pada jurusan Sejarah Universitas Gadjah Mada.

Sjahrir, Renungan Indonesia, Jakarta: Pustaka Rakyat,1951.

Sjahrir, Our Struggle, translated and with introduction BenedictR.O.G Anderson, Ithaca: Cornell University, 1968.

Kemenangan di Lake Success, Tempo, 09 Maret 2009.

Charles Wolf, The Indonesian Story: The Birth, Growth, and Structure of the Indonesian, New York: The John Day Company, 1948

S. Hardjosoediro, Dari Proklamasi ke Perang Kemerdekaan. Balai Pustaka, 1987.

Salim Said, Genesis of Power: General Sudirman and the Indonesian Military in Politics 1945-49

(Singapore: Institute of Southeast Asian Studies, 1991

Majalah Tempo, 30 September 2001

Linggarjati, Sebuah Jalan, Tempo, 09 Maret 2009

Koran Ikhwanul Muslimin, 5 Oktober 1947

Interview/Talks with Rushdy Hussein, a historian, Jakarta March $2009 .$.

Interview with the late Soedjatmoko in Jakarta, early April 1988

Interview with the late Soebadio sastrosatomo in Jakarta, early March 1990

Interview with the late Sarbini Sumawinata in Jakarta, June 1990 